\title{
Resilient Rural Areas and Tourism Development Paths: A Comparison of Case Studies
}

\author{
Antonietta Ivona ${ }^{1, *(\mathbb{D}}$, Antonella Rinella ${ }^{2} \mathbb{D}$, Francesca Rinella ${ }^{1}$, Federica Epifani ${ }^{3}$ and Sara Nocco $^{2} \mathbb{D}$ \\ 1 Department of Economy and Finance, University of Bari, 70100 Bari, Italy; francesca.rinella@uniba.it \\ 2 Department of History Society and Human Studies, University of Salento, 73100 Lecce, Italy; \\ antonella.rinella@unisalento.it (A.R.); sara.nocco@unisalento.it (S.N.) \\ 3 Department of Cultural Heritage, University of Salento, 73100 Lecce, Italy; federica.epifani@unisalento.it \\ * Correspondence: antonietta.ivona@uniba.it
}

Citation: Ivona, A.; Rinella, A.; Rinella, F.; Epifani, F.; Nocco, S. Resilient Rural Areas and Tourism Development Paths: A Comparison of Case Studies. Sustainability 2021, 13, 3022. https://doi.org/10.3390/ su13063022

Academic Editors: Marc A. Rosen and Piotr Prus

Received: 12 January 2021

Accepted: 5 March 2021

Published: 10 March 2021

Publisher's Note: MDPI stays neutral with regard to jurisdictional claims in published maps and institutional affiliations.

Copyright: (C) 2021 by the authors. Licensee MDPI, Basel, Switzerland. This article is an open access article distributed under the terms and conditions of the Creative Commons Attribution (CC BY) license (https:// creativecommons.org/licenses/by/ $4.0 /)$.
Abstract: In the settlement network of Italian small towns (the so-called "borghi", with a population ceiling lower than 5000 inhabitants), not lacking in discontinuities and patches, a "common thread" is increasingly noticeable, which allows to look optimistically beyond several weaknesses (economy depending on a relatively unprofitable or declining agriculture, social and economic stasis, demographic decline and consequent contraction of public and private services, hydrogeological instability, etc.): we are talking of the firm, pigheaded determination of an increasing number of local communities to become sustainable and responsible realities, get involved, and undertake a process of "hot authentication" of their milieu. Since 2013, such resilient attitude is at the heart of the National Strategy for Inner Areas (SNAI, Strategia Nazionale per le Aree Interne) aimed at promoting coordinated, multi-scalar projects of self-enhancement; in April 2019, the above innovative form of territorial planning was selected by the European Parliament as a model for the 2021-2027 programming period of the European Regional Development Fund (ERDF).This paper reviews the original and creative bottom-up enhancement process being implemented in several towns of the "Monti Dauni" sub-region, a pilot marginal area identified by Apulian regional authorities within the SNAI. In these small towns, local players aim at maximizing the opportunities of sustainable, experiential tourism by offering an uncontaminated environment, ancient knowledge, genuine flavours and deep emotions to all visitors who wish to achieve a deeper knowledge of the territorial identity instead of being mere spectators, by adopting an active and engaged attitude.

Keywords: marginal areas; National Strategy for Inner Areas (SNAI; Strategia Nazionale per le Aree Interne); sustainable local development; experiential tourism

\section{Introduction}

The long-standing issue of Italian inner areas lack of development has been periodically debated by the scientific and political community.

In Italy, inner areas are territories significantly distant from key welfare services (health, education, and mobility) but, at the same time, they are characterized by a huge amount of territorial capital in terms of environmental and cultural resources, highly diversified in nature and as a consequence of anthropization processes [1].

These areas represent the $60 \%$ of the whole national territory, organized in 4000 municipalities of small-medium size (the majority of borghi, small towns up to 5000 inhabitants, are located in inner areas) and host one-quarter of the Italian population [2].

The one above is a functional, political-strategic definition, which inspired the outlining of the National Strategy for Inner Areas (Strategia Nazionale per le Aree Interne, from now on SNAI). However, it is in turn the result of a rooted scientific debate about the essential features of these territories, as well as their intrinsic dynamics.

For a long time, such a debate was driven by an historical approach, aimed at a better understanding of the origins of Inner Areas: these can be traced to the 1950s, when Italian 
national development strategies were largely inspired by growth pole models. The main spatial effect was an increasing gap between industry-driven territories and, in a second phase, also tourism-driven-, mainly located in lowlands and coastal areas, and rural areas. The latter, for decades, served as a reservoir of resources and labour for developed areas, and progressively faced heavy depopulation, loss of biodiversity and cultural heritage, and environmental degradation.

The following insurgence of diseconomies of agglomerations within the growth poles are the reason for a rediscovery, during the nineties, of local dimension: both policymakers and scholars look at those which had been known as "marginal" areas as a valid alternative for a new idea of development. Hence, it is self-evident that inner areas are far from being just peripheral areas: on the contrary, they resemble an extremely varied scenario, characterized by heavy threats but, at the same time, gifted with a meaningful territorial potential.

The analysis of the causes of their progressive decay and, therefore, the possible remedies, followed historically at least three approaches. The so-called "conservative" one, suggested keeping a minimum level of services for the population in order to discourage the abandonment. With the second approach, the "compensatory" one, the definitive departure of traditional residents was accepted but measures were put forward to attract new ones. The third approach, the "multifunction" one, derived by the overlapping of the concepts of inner area and rurality, both expressing territorial marginality. "However, the (structural) marginality is indeed connected to rurality: actually, it can be sufficiently proven that most of the rural areas where agriculture plays a dominant (though weak) role and featuring a low economic and social level, much lower than urban and industrial areas, are to be considered marginal areas" [3]. The "multifunction" approach suggested the integration of the specific production targets of the usual agricultural activity of the concerned areas, with more innovative ones, related to the increasing demand of suburban social spaces, such as those related to tourist accommodation offerings, and the sale of typical and/or food and wine products. Notwithstanding several measures put forward by different successive governments, the situation of inner areas still shows, in some cases, marginality features, though with differences across each territory. Further, the economic and financial crises of recent years, increased the challenges of weaker areas such as, for example, the Appennini or, more in general, southern Italy. Given the above, it is more necessary than ever to reconsider a new development model mainly driven by the recovery of such disadvantaged areas, better known as "inner areas".

This paper, after introducing the main features of the new approach followed by the National Strategy for Inner Areas (SNAI) reviews the original and creative bottom-up enhancement process being implemented in several towns of the "Monti Dauni" sub-region, a pilot inner area identified by Apulian regional authorities within the SNAI. Within these small towns, following the established principles of sustainability and social cohesion [4], local players aim at maximizing the opportunities of sustainable, experiential tourism by offering an uncontaminated environment, ancient knowledge, genuine flavors, and deep emotions to all visitors who wish to achieve a deeper knowledge of the territorial identity instead of being mere spectators, adopting an active and engaged attitude.

\section{The New Multi-Scalar Approach of the National Strategy for Inner Areas in Italy}

For many years, at first in the scientific then in the political context, the question has been raised about the meaning of inner areas in order to define and include them in the accompanying measures for the development. After a long series of interventions focused on cities as driving centres of development, for more than twenty years Geography has been trying to "explore the role played by some inner areas within the process of territorial change" [5] (p. 7). This new research stage was firstly focused on southern regions seen as part of a more structured process for the revalorisation of those areas of the country lagging behind in terms of development and considered marginal [6]. Starting from the period after the Second World War, State interventions had been dictated rather 
by emergencies (Cassa per il Mezzogiorno) or contingencies of specific cases (earthquakes and/or other natural disasters), than by the planning of structural and specific measures designed for marginal areas. Therefore, such interventions, had not created a new consistent economic structure. In particular, concerning inner areas, Coppola wrote: "once again, the core of Mezzogiorno, defined as a number of inner and less accessible areas, not only for their position and physical connections but also — and often, above all-in terms of social distance and cultural attitudes, has remained in shade" [7] (p. 4). Afterwards, scholarly focus expanded to include the rest of Italy, in the conviction that the marginal nature, typical of the southern core, was a common feature of all the inner areas [8-11] and that the analysis should be expanded, therefore, to the whole national territory.

The acknowledgement of the lagging condition of the country's inner areas leads the Government to promote a plan for their relaunch. Thus, since 2013, a national strategy coordinated by the Prime Minister's Office has been implemented, called National Strategy for Inner Areas (SNAI), concerning 72 "project areas" in all the Regions and in the Autonomous Province of Trento, selected through indicators related to the access to health services, collective mobility and education. The municipalities involved are 1066 on the $16.7 \%$ of the country's area, with about 2.1 million inhabitants equal to $3.5 \%$ of the national population [2].

The urgent need of government action is confirmed by several considerations: inner areas represent a large part of the country-about three fifths of the territory and little less than a quarter of the population - highly diversified internally, far from big agglomeration and service centres and with unsteady development trajectories, and yet endowed with resources lacking in central areas, with demographic issues but also strongly polycentric and with a high potential for attraction. The SNAI defines them as those parts of the national territory affected by population decrease or ageing and in which the weak development prospects lead to increasing difficulty in the living conditions of their inhabitants [2]. In its National Reform Programme (NRP), a document annually defining for each EU Member State the measures to be adopted in order to achieve the national targets in terms of growth, productivity, employment, and sustainability set by the Europe 2020 strategy [12], Italy adopted a strategy aiming to counteract the demographic decline and relaunch the development and the services of those areas through the regular lending of the Stability Law and EU funds. Together with the Politiche per le Città (Urban Policies) the SNAI represents the backbone of the territorial planning defined by the Italian Government in the 2014-2020 programming cycle. In order to guarantee the effectiveness and sustainability over time of the above strategy, in line with the Partnership Agreement for the use of structural funds allocated to Italy for the 2014-2020 programming cycle, in the Stability Law of 2014 (Articles 13 and 17) [13] an expenditure of EUR 3 million for 2014 and EUR 43.5 million for each of 2015 and 2016 was authorised, to be financed by the Revolving Fund. The resources are allocated for the financing of pilot interventions to rebalance the basic service offer in the country's inner areas, with a focus on transport, education as well as social and health services. By September of each year, the Minister for Territorial Cohesion submit to CIPE (Comitato Interministeriale per la Programmazione Economica) the results of the actions carried out, for the purposes of the refinancing assessment for the following year. Italy adopted this strategy to counteract the demographic decline and relaunch the development and services of those areas by allocating about EUR 180 million of national funds, in addition to regional funds from programmes financed through European funds. To achieve these goals, the strategy foresees two converging lines of action: one, aimed at driving the local development through projects funded by the available European regional funds (ERDF Regional Operational Programme, ESF Regional Operational Programme, and Rural Development Programme); the other, aiming to provide to the same areas suitable levels of citizenship in some essential services (health, education, and mobility). The latter category of actions received an overall national allocation of EUR 90 million within the Stability Law of 2014, to support interventions in the first 23 pilot areas, and additional EUR 90 million are planned for the three-year period 2015-2017. The entity coordinating 
the National Strategy for Inner Areas is the Committee for Inner Areas (CAI, Comitato Aree Interne) a national body that interfaces with Regions and the selected pilot areas.

The SNAI combines to Law No. 158/2017, "Measures for the support and the enhancement of small towns, as well as provisions for the revitalisation and recovery of their historic centres" [14], with an allocation of EUR 100 million for the 2017-2023 period. The resources are also intended to finance investments for the protection of the environment and cultural heritage, the mitigation of the hydrogeological risk, the safety of road infrastructure and schools, the establishment of new production activities; as well as the design and implementation of the national network of tourist cycle routes and safety interventions for urban traffic. Beneficiaries of the initiatives are the towns with less than 5000 inhabitants, located in concerned areas characterised by hydrogeological instability, decrease of resident population, settlement unease, inadequacy of essential social services. The Italian towns meeting the above criteria are 5591 , or $70 \%$ of the total national number.

Geographically, it is interesting to notice how one of the main strengths of the SNAI is its being a successful example of placed-based local development policy. Indeed, SNAI adopts a mixed top-down/bottom-up approach, aiming to systemize all the financing measures available in the "project areas", fostering both the vertical and horizontal cooperation; the multi-scalar structure is functional to achieve a local development process on an endogenous and self-centered basis, within an empowering framework created by supra-local measures.

As a planning tool, SNAI is an expression of a political-strategic dimension according to which the development of Inner areas represents a priority in the Italian political agenda, also due to the territorial and demographic size of the phenomenon. Throughout the whole document and the implementation processes it is possible to recognize an evolutionary approach, based on the definition of a shared territorial vision to drive and inspire local stakeholders.

If, on one hand, this could bring territories to develop a sort of performative attitude, in order to put national and super local instructions into practice, on the other hand the way through which each territory assimilates such an input depends on their specific autopoietic territorial capital, namely, that set of site-specific features through which local stakeholders rework external inputs and adapt them to the milieu.

For these reasons, in the next paragraphs, along the presentation of Monti Dauni as a paratactic space [15] outlined by the political action, we deal with the results of direct and indirect observation of some of its sub-areas which we consider as proactive, relational spaces $[16,17]$ where situated practices take place. Such practices are preexistent to SNAI, and can suggest interesting development trends to the whole pilot area

\section{The Monti Dauni As SNAI Pilot Area: Overview}

Little more than 56,000 inhabitants on about 2000 square $\mathrm{km}$ of gently sloping clay hills, "often carved out by deep torrential valleys, partly faulted or extensively ripped apart by erosion processes" [18] (p. 12), framing the Tavoliere di Puglia to the West and South-West and rarely exceeding $1000 \mathrm{~m}$ a.s.l. (the maximum altitude is that of Monte Cornacchia-1151 $\mathrm{m}$ a.s.1.): this is the loose anthropic fabric of the Monti Dauni (in the past often referred to in several geographical essays as "Subappennino Dauno") [19-23]. It is composed of 29 municipalities spread over two rows of topmost villages similar to lonely "Nativity scenes" [24] (p. 34). These little towns gradually depopulated since 1950s [23] (p. 509) [25] (p. 9), confirming the poor demographic endowment of the sub-region starting from the first years of 1900 [26] Table 1. 
Table 1. Monti Dauni: altitude, area, and comparison of demographics 1991/2019 (Source: our processing of ISTAT data).

\begin{tabular}{|c|c|c|c|c|c|c|c|c|c|}
\hline & $\mathbf{I}$ & II & III & IV & $\mathbf{V}$ & VI & VII & VIII & IX \\
\hline MUNICIPALITIES & $\mathrm{m}$ a.s.l. & sq. km. & $\begin{array}{l}\text { pop. } \\
1991\end{array}$ & $\begin{array}{l}\text { pop. } \\
2019\end{array}$ & $\begin{array}{c}\text { inh./sq. } \\
\text { km. } \\
1991\end{array}$ & $\begin{array}{c}\text { inh./sq. } \\
\text { km. } \\
2019\end{array}$ & $\begin{array}{c}(\mathrm{IV}-\mathrm{III}) / \mathrm{III} \\
\%\end{array}$ & $\begin{array}{c}\%>75 \\
\text { years old } \\
1991\end{array}$ & $\begin{array}{c}\%>75 \\
\text { years old } \\
2019\end{array}$ \\
\hline Accadia & 650 & 30.48 & 3107 & 2277 & 101.94 & 74.70 & -26.71 & 10.7 & 13.2 \\
\hline Alberona & 732 & 49.25 & 1269 & 902 & 25.77 & 18.31 & -28.92 & 11.6 & 18.6 \\
\hline Anzano di Puglia & 760 & 11.12 & 2365 & 1185 & 212.68 & 106.56 & -49.89 & 7.4 & 14.8 \\
\hline Ascoli Satriano & 393 & 334.57 & 6892 & 6102 & 20.60 & 18.24 & -11.46 & 6.6 & 10.6 \\
\hline Biccari & 450 & 106.31 & 3462 & 2696 & 32.57 & 25.36 & -22.13 & 7.9 & 16.8 \\
\hline Bovino & 620 & 84.16 & 4546 & 3138 & 54.02 & 37.29 & -30.97 & 10 & 16.9 \\
\hline Candela & 474 & 96.14 & 2809 & 2732 & 29.22 & 28.42 & -2.74 & 8.3 & 10.6 \\
\hline Carlantino & 558 & 34.17 & 1449 & 916 & 42.41 & 26.81 & -36.78 & 6.8 & 16.1 \\
\hline $\begin{array}{l}\text { Casalnuovo } \\
\text { Monterotaro }\end{array}$ & 432 & 48.17 & 2370 & 1434 & 49.20 & 29.77 & -39.49 & 12.1 & 16.8 \\
\hline $\begin{array}{c}\text { Casalvecchio di } \\
\text { Puglia }\end{array}$ & 465 & 31.70 & 2410 & 1763 & 76.03 & 55.62 & -26.85 & 6.8 & 14.3 \\
\hline $\begin{array}{l}\text { Castelluccio dei } \\
\text { Sauri }\end{array}$ & 284 & 51.31 & 1900 & 2097 & 37.03 & 40.87 & 10.37 & 7.4 & 10.3 \\
\hline $\begin{array}{l}\text { Castelluccio } \\
\text { Valmaggiore }\end{array}$ & 630 & 26.66 & 1552 & 1253 & 58.21 & 47.00 & -19.27 & 10.1 & 18.4 \\
\hline $\begin{array}{l}\text { Castelnuovo } \\
\text { della Daunia }\end{array}$ & 543 & 60.99 & 1991 & 1359 & 32.64 & 22.28 & -31.74 & 9.6 & 15.9 \\
\hline $\begin{array}{l}\text { Celenza } \\
\text { Valfortore }\end{array}$ & 480 & 66.48 & 2299 & 1485 & 34.58 & 22.34 & -35.41 & 10.7 & 28.2 \\
\hline Celle di San Vito & 726 & 18.21 & 297 & 164 & 16.31 & 9.01 & -44.78 & 14.1 & 21.3 \\
\hline Deliceto & 575 & 75.63 & 4304 & 3671 & 56.91 & 48.54 & -14.71 & 9.8 & 12.5 \\
\hline Faeto & 820 & 26.16 & 1010 & 614 & 38.61 & 23.47 & -39.21 & 13.6 & 11.1 \\
\hline $\begin{array}{l}\text { Monteleone di } \\
\text { Puglia }\end{array}$ & 842 & 36.04 & 1608 & 977 & 44.62 & 27.11 & -39.24 & 13.2 & 12.3 \\
\hline $\begin{array}{c}\text { Motta } \\
\text { Montecorvino }\end{array}$ & 662 & 19.7 & 1159 & 682 & 58.83 & 34.62 & -41.16 & 13.5 & 23.6 \\
\hline Orsara di Puglia & 635 & 82.24 & 3530 & 2604 & 42.92 & 31.66 & -26.23 & 9.9 & 17.6 \\
\hline Panni & 801 & 32.59 & 1083 & 740 & 33.23 & 22.71 & -31.67 & 15.8 & 21.6 \\
\hline Pietramontecorvino & 456 & 71.17 & 3111 & 2612 & 43.71 & 36.70 & -16.04 & 10.1 & 14.7 \\
\hline $\begin{array}{c}\text { Rocchetta } \\
\text { Sant'Antonio }\end{array}$ & 633 & 71.9 & 2293 & 1767 & 31.89 & 24.58 & -22.94 & 9.5 & 15.5 \\
\hline Roseto Valfortore & 658 & 49.61 & 1513 & 1054 & 30.50 & 21.25 & -30.34 & 18 & 17.7 \\
\hline $\begin{array}{c}\text { San Marco la } \\
\text { Catola }\end{array}$ & 683 & 28.4 & 1794 & 925 & 63.17 & 32.57 & -48.44 & 9.6 & 17.8 \\
\hline $\begin{array}{c}\text { Sant'Agata di } \\
\text { Puglia }\end{array}$ & 794 & 115.79 & 3049 & 1886 & 26.33 & 16.29 & -38.14 & 12.9 & 15.2 \\
\hline Troia & 439 & 167.22 & 7898 & 6985 & 47.23 & 41.77 & -11.56 & 6.8 & 12.7 \\
\hline Volturara Appula & 526 & 51.87 & 744 & 397 & 14.34 & 7.65 & -46.64 & 18 & 23.8 \\
\hline Volturino & 735 & 58.02 & 2224 & 1654 & 38.33 & 28.51 & -25.63 & 9.1 & 27.2 \\
\hline TOTAL & & 1936.06 & 74,038 & 56,071 & 38.24 & 28.96 & -24.27 & 9.6 & 14.4 \\
\hline
\end{tabular}


In the face of the unrelenting long-term dissipating capitalization [27] (p. 316) in process, characterized by the depletion of physical components (hydrogeological instability, stream overflow, and deforestation) as well as anthropic ones ("angry" migration [21] (p. 172)—abandonment of built-up areas, population ageing, and decrease of traditional directly managed agricultural activities - mainly extensive cereal production and sheep farming), Mannella [18] in 1990 wrote that "by paraphrasing Banfield [28], the image offered by the population does not look like a community's one, that is a significant social structure, but a mere aggregation of families within the boundaries of a geographical area" [18] (pp. 27-28), unable to stop the decline of the "uprooted" mountain.

The 1991-2019 period confirms the trend strengthened in the previous decades: indeed, ISTAT data show a decrease in the population from 74,038 to 56,071 inhabitants $(-24.27 \%)$, more than halved compared to the anthropic coverage surveyed in 1961 . The demographic decrease concerns the whole area, with only the exception of Castelluccio dei Sauri $(+10.37 \%)$ and, above all, the innermost and/or higher towns (Anzano di Puglia: -49.89\%; San Marco la Catola: -48.44\%; Monteleone di Puglia: -39.24\%; Faeto: -39.21\%) (see Table 1; Figure 1). The settlement system, almost devoid of population, scattered in the countryside [14], has only four towns with more than 3000 inhabitants (Ascoli Satriano: 6102; Bovino: 3138; Deliceto: 3671; Troia: 6985) and is scattered in 15 villages with less than 1500 inhabitants, including Celle di San Vito, the smallest Apulian municipality (164 inhabitants).

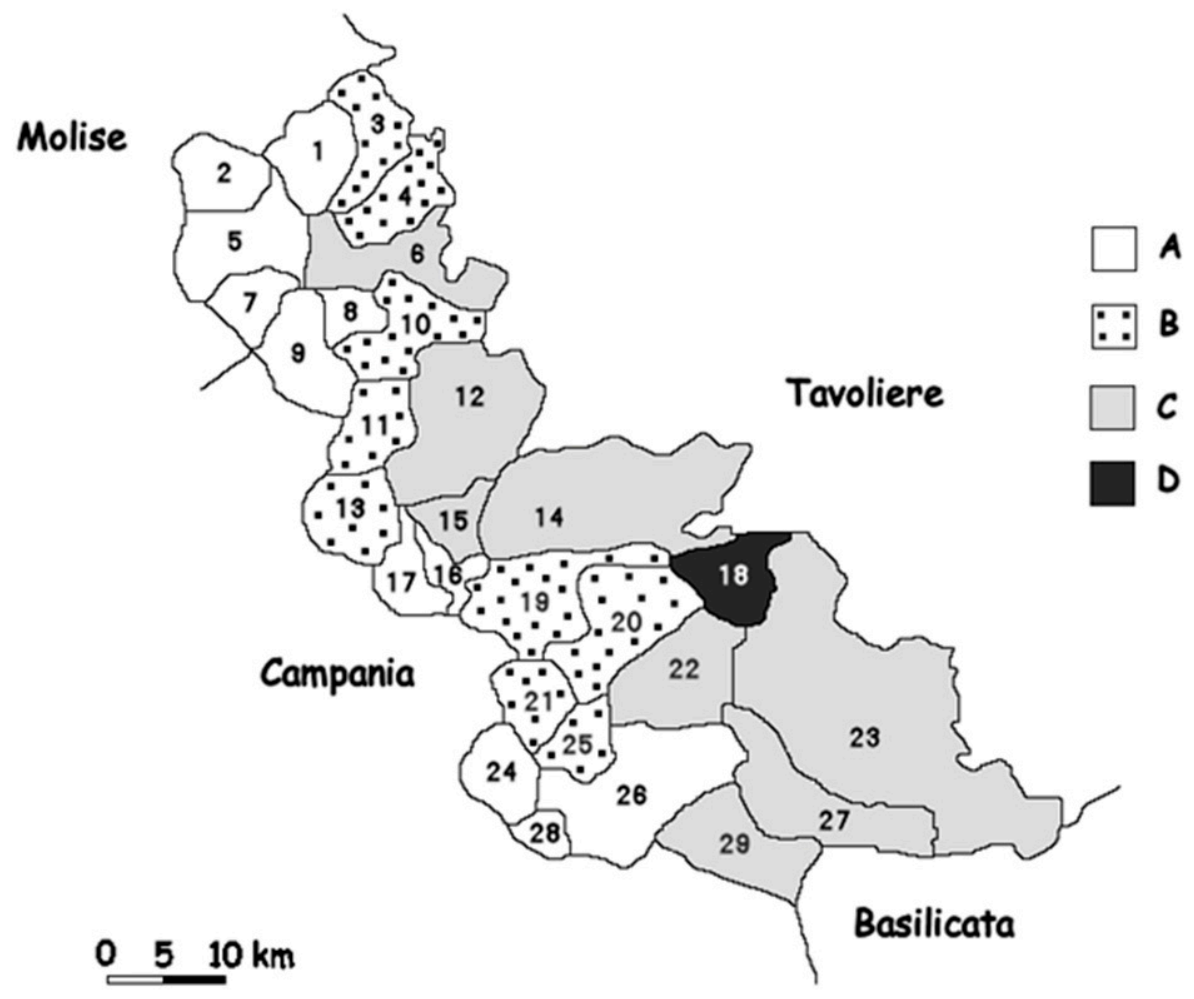

Figure 1. Monti Dauni: percentage change of inhabitants in the 1991-2019 period (our processing of ISTAT data). (A: > -35\%; B: between $-35 \%$ and $-24.27 \%$; C: between $-24.27 \%$ and 0; D: positive percentage changes). (1: Casalnuovo Monterotaro; 2: Carlantino; 3: Casalvecchio di Puglia; 4: Castelnuovo della Daunia; 5: Celenza Valfortore; 6: Pietramontecorvino; 7: San Marco la Catola; 8: Motta Montecorvino; 9: Volturara Appula; 10: Volturino; 11: Alberona; 12: Biccari; 13: Roseto Valfortore; 14: Troia; 15: Castelluccio Valmaggiore; 16: Celle di San Vito; 17: Faeto; 18: Castelluccio dei Sauri; 19: Orsara di Puglia; 20: Bovino; 21: Panni; 22: Deliceto; 23: Ascoli Satriano; 24: Monteleone di Puglia; 25: Accadia; 26: Sant'Agata di Puglia; 27: Candela; 28: Anzano di Puglia; 29: Rocchetta Sant'Antonio). 
At the same time, population ageing goes on: people over 75 grew (from 7092 to 8089 units, up from $9.6 \%$ to $14.4 \%$ of total resident population), in less populated towns, mainly upland, they account for more than one-fifth of the population (Celenza Valfortore: 28.2\%; Volturino: 27.2\%; Volturara Appula: 23.8\%; Motta Montecorvino: 23.6\%; Panni: 21.6\%; Celle di San Vito: $21.3 \%$ ).

The demographic decline exacerbates the chronic lack of essential services (school, health, and public services) and, above all, the difficulty experienced in protecting a wide range of environmental and cultural heritage $[29,30]$ and to promote their enjoyment by tourists. The Piano Paesaggistico Territoriale Regionale della Puglia (Regional Territorial Landscape Plan for Apulia) [31] among the its main issues highlights the soil and subsoil disruption (natural phenomenon exacerbated by demographic depletion, poor maintenance, and unsustainable forms of agricultural transformation for production purposes of extensive slope areas), the loss of biodiversity and of important crop varieties, the abandonment of rural buildings, the quick disqualification of the historic centres involved in few, limited recovery actions and, paradoxically, the increase of urbanised areas, even due to senseless accommodation initiatives funded by Law No. 64/1986 [32]. The document also states that "only in a few towns (..)a policy for the protection of local production identities, effective policies to foster tourism and private initiative in quality restaurants allowed the recovery of ancient vines and support farming and cheese-making" [31] (p. 17).

The LEADER Plus 2014-2020 planning document of the local action group (LAG) Meridaunia (the Monti Dauni development agency that, since 1998, has been promoting interventions and project actions of the Local Development Plan in the area) [29], points out that, despite the sub-region being granted several EU, national, and regional funds, there is a long way to go to achieve an integrated system of tourist enjoyment: indeed, during prior consultation, the LAG noticed a deep dissatisfaction among visitors, "obliged to deal with a multitude of entities (many accommodation facilities, several proloco for guided tours, etc.)" as well as the weakness of hospitality services (with the only exception being restaurants) since "at present there aren't any major consortia or associations nor any natural inclination towards bundling/cooperation was found, both horizontally (among players of the same sector) and vertically (among players of different sectors); on the contrary, an inclination towards individualism/chauvinism was detected, the first one among players, the latter among municipalities" [29] (pp. 18-19).

The above considerations confirm the need to replace individual public/private players receiving funds with a whole community, as the main player of self-governance, able to "re-read the territory" to "return to the mountain", to propose (to itself and outsiders) the narration of a new "cornerstone" to build "an alternative geography to the extremely fast, crowded and noisy metropolitan spaces" [33] (p. 18), not a "stone rejected", a fragile, marginal, inland, peripheral place. A closed community in regulatory terms but functionally open to the opportunities offered by "networking", that develop in Italy thanks to the activity of several local collective entities which, in aggregate form and from below, offer a unitary image of villages through the Internet, as "Borghi Autentici d'Italia" (BAI) [34] and "Borghi più belli d'Italia" [35]. Such forms of association tend to promote "virtual" agglomeration economies, able to overcome the critical minimum threshold (in terms of capital, human resources, infrastructure, tourist demand) that in each single village may constitute an obstacle to shared and successful projects of sustainable development getting off the ground.

By Decision No. 870 of April 2015 [36], the Regional Council of Apulia identified the Monti Dauni as the first pilot area of the SNAI, comprising the above-mentioned 29 municipalities and the municipality of Lucera (32,506 inhabitants), a thriving agricultural center of the Tavoliere di Puglia, already connected to the Sub-Apennine through projects for the economic, territorial, and rural development (Pianificazione strategica di Area Vasta, Leader, PIT Puglia n. 10), welfare, and health, which takes part to the definition of this new area strategy as indirect beneficiary of the initiatives. As stated in the Regional Decision No. 951/2018, after long negotiations among all the players involved, "to implement the 
Strategy all the available financing sources have been integrated: the funds of the Stability Law for ordinary policies on essential services, equal to EUR 3,750,000, the 2014-2020 ERDF/ESF ROP resources (EUR 40.000.000), as set forth in the operational programme approved by the European Commission in August 2015. Further, Apulian regional authorities, in their 2014-2020 Rural Development Plan and in the ROP, rely on the community lead local development (CLLD) to reinforce the SNAI through dedicated resources. Thanks to this opportunity, the Conference of Mayors of the Monti Dauni Inner Area, decided to include the interventions and the SNAI additional resources of the PSR PUGLIA 2014-2020 (EUR 17,000,000) and those coming from the 2014-2020 ERDF/ESF ROP (EUR 3,000,000) in the Monti Dauni Local Action Plan (LAP), prepared by the LAG Meridaunia for initiatives in line with the Strategy. Therefore, the Inner Area Strategy can rely on a total allocation of EUR 63,750,000" [37]. In particular, about EUR 8 million are allocated to initiatives aimed at the promotion and enjoyment of the cultural heritage. Such resources, in our opinion, could contribute to support and spread some municipal good practices already present in the sub-region, also developed thanks to the above-mentioned spontaneous associative forms [34,35], that we will discuss in the following paragraphs.

The study we propose about the ongoing experiences within the territories of Monti Dauni is not functional to the evolutionary analysis of territorial performances, perhaps through the use of quali-quantitative indicators. We rather believe it is more interesting to follow a narrative approach focusing on the fluidity of ongoing processes as the result of the interaction among participating bodies [38]. These are at the same time intrinsically oriented and influenced by the material context at individual level and able to re-direct and re-define it through specific relational configurations. Such configurations appear specifically located within a space which is at the same time differential and differentiating [38,39].

Pragmatically, SNAI identified and delimited its target areas according to precise criteria of proximity, as well as geomorphological, cultural, and historic-institutional homogeneity. Furthermore, the Monti Dauni area is the result of such a kind of regionalization. In other terms, the area of Monti Dauni is clearly differentiated from its surrounding. Nevertheless, the area is far from being uniform: the functional geography of the Monti Dauni as an inner area overlaps with the micro-geographies of the situated practices. These are spatial-relational assets which are often the result of processes which have settled down over time; specifically, they are univocally locatable, they cross the objectives of the SNAI and contribute to their implementation, determining their success, but they are pre-existing and, unlike them, not always and not necessarily measurable. Since these arrangements are not uniform, it follows that the micro-geographies of the situated practices give a differentiated space, on which the very implementation of the SNAI objectives depends, and therefore it is not necessarily uniform

It is on the investigation of situated practices, of hidden practices, of minor actors, which this work focuses on a better understanding of the here and now, rather than on the performative evaluation of the territories, which risks activating homologating competitive attitudes that are not sustainable in endemically fragile territories.

\section{Experiential Tourism as a Form of Resilience}

In recent years, tourism underwent a deep change, evolving and transforming itself alongside the multiplication of the reasons leading a tourist to prefer a given destination: actually, where traditionally the attractiveness of a destination depended mainly on the beauty of its landscape, monuments, or architecture. In the contemporary scene the needs underlying tourist's choices are increasingly diverse and difficult to figure out. This is the reason why the new strategies of the tourist market do not focus on the sale of "places to visit" any longer, but on "destinations to be experienced" [40], able to offer new opportunities for reflection and unusual emotions to all those tourists who wish to keep an increasingly watchful eye to the territorial identity, connecting with its population, and getting emotionally involved in order to become an integral part of a community instead of 
being a mere observer. A growing interest in "back regions" [41,42], that is, "those spaces of rootedness where the dwelling of residents is believed (or imagined) as still possessing a character of genuineness" [43] (p. 513), is perceived in such "experiential" [44,45] visitors, as well as in tourist operators, in clear contrast with the increasing commodisation of the "front regions". Such genuineness is mainly provided through social relations arising among tourists and the local community $[46,47]$. This leads to a deep change in the whole tourist system, not only on the demand side, but on the supply side as well, at the centre of which the local communities place themselves, allowing the territory to be known, experienced and appreciated in all its aspects, transforming visitors in temporary citizens who wish to discover realities often remaining outside of the main traditional tourist routes.

The key role of the local community is based on the strategic project "Comunità Ospitali" (CO), promoted in 2012 by Borghi Autentici d'Italia (BAI)—an association of 250 small towns that since 2007 have been making local communities the focus and key element for the relaunch of the unique features of each place [34,48]—with the implementation of the Rete Nazionale Comunità Ospitali co-funded by the MiBACT (Ministry for Cultural Heritage and Activities and for Tourism). The villages participating in the project are not simple traditional tourist destination, but represent "inclusive", "interpersonal destinations" designed to offer tourists not only a product, but a real travel experience towards genuineness, fostering opportunities for new businesses and a path towards economic and social growth which becomes sustainable thanks to the integration, interaction, and coordination capacity of all the elements and the players, the private as well the public ones.

An interesting example of aggregation aimed at promoting a wide cooperation among municipalities in the same area is the "Sistema delle Comunità Ospitali dei Monti Dauni" that, unlike most of the COs, made of single municipalities or a limited number of neighbouring local entities, involves all the 30 municipalities of the pilot area (see $\S 3$ ). The purpose of the system, set up on 2 March 2017 and composed of seven COs, is to create an integrated system for the enhancement of local cultural, religious, landscape, food, and wine excellences, by making the Subappennino Dauno a competitive area on the national and international market [49].

The COs are aware that the creation of a strong synergy among the territory players (accommodation facilities and restaurants, craft and agri-food businesses, associations, proloco, and tourist guides) as well as the networking of all the local resources (cultural, environmental, food and wine heritage, events, stories, legends, tales, and anecdotes) are essential in order to offer a real tourist experience to empirical visitors. The municipalities participating in the project try to promote hospitality through different instruments: the Casa dell'Ospite (House of Guests), to concentrate organizational functions and carry out common activities (exhibits, tasting sessions, events, etc.); the RRD, Rete Ricettiva Diffusa (widespread hospitality network) aiming at the recovery and enhancement of the (public or private) abandoned or underused architectural heritage in order to create a widespread system of accommodating units in the historic centre; the Cartellone Unico (single programme) of events, designed to guarantee the resource optimization; the crucial professional and relational role of the tutor, who welcomes and assists guests not as a simple tourist guide, but as an advisor, an accompanying friend, and a guardian of stories and tales known only to the village inhabitants, making the holiday a memorable experience, a travel in the spirit of the village and of its inhabitants; the Botteghe dei Sapori Autentici (stores of authentic flavours), shops for the enhancement of the food and wine heritage.

The types of holiday that certainly involve a particularly marked experiential dimension include the gourmet holiday which, over time, became a useful means to know a territory culture "thanks to its ability to convey those values so sought-after by contemporary tourists, that is genuineness, sustainability, experience, respect for heritage and local identity" [50] (p. 7). Food and wine are a strength to exploit, especially in those territories that, though having a strong cooking and winemaking tradition, are located in marginal areas which, nevertheless, through the enhancement of typical products are able to become unique and one-of-a-kind territories, creating a concrete opportunity for 
local development [49]. The awareness that food is now an integral part of Italian cultural heritage as well as of the worldwide image of the Bel Paese, lead the MiBACT and the MiPAAF (Ministry for Agricultural, Food and Forest Policies) to designate 2018 as the "L'Anno del cibo italiano" (year of the Italian food), a decision that, in turn, induced BAI to create the patchwork of projects "Comunità del cibo buono e autentico" (communities of good and genuine food), aimed at promoting a form of experiential tourism linked to food and wine traditions, especially for what concerns the genuineness and simplicity of local typical products considered as a set of values, a background, an important heritage, a legacy with ancient roots [51]. The project, launched on 23 March 2018 at BAI National Meeting in Sestri Levante, closed on 30 September 2018 on the occasion of the third BAI National Day on the theme of "Food and wine: a community pride". Forty-seven villages decided to participate to the closing event, by organizing their own programme on different activity lines proposed by the Association and creating a rich and extremely varied event calendar with 15 different types of local initiatives. The 16 Apulian municipalities that actively participated to the event also included one of the villages of the Monti Dauni: Castelluccio Valmaggiore.

\subsection{Castelluccio Valmaggiore and the Project "Comunità del Cibo Buono e Autentico"}

Castelluccio Valmaggiore, a municipality of the "Sistema delle Comunità Ospitali dei Monti Dauni" and belonging to the "Monte Cornacchia" C—-to which the municipalities of Alberona, Biccari, Celle San Vito, Faeto, and Roseto Valfortore also belong - owes the name of "Castelluccio" to the little castle built around 1300 that housed the Governor of the Feud while "Valmaggiore" refers to its geographical position dominating the whole Celone valley. The municipality, located at an altitude of $630 \mathrm{~m}$ a.s.l., extends on an area of 26.66 square $\mathrm{km}$, has 1253 inhabitants, with a density of 47 inhabitants/square $\mathrm{km}$.

Participating to the final day of the event "Comunità del cibo buono e autentico", the municipality showed the great importance it attaches to the enhancement not only of the tangible heritage (environmental and cultural resources), but of intangible legacy as well, by organizing several historical and anthropological events (folk dances and songs, ancient street games, and historical parades), a necessary contribution for spreading the culture and knowledge of the territorial traditions seen as an essential instrument to develop the tourist image and economy [52]. Further, it organized food markets and stands and proposed tasting of typical products and dishes (cereals, vegetables, grapes, olives, orecchiette and fusilli, cacio, caciocavallo and cacioricotta, sfogliata with onions, and pettole) to promote the territorial discovery through the excellent and typical products that make it unique. Through the initiatives put in place by the municipal administration in cooperation with the inhabitants, the associations and the local producers, visitors were able to live and share the past and present spirit of the place, becoming familiar with the territory. At their arrival, after purchasing the daily voucher (EUR 12) to get their breakfast and lunch, tourists were welcomed in Piazzetta Piscero by the "street band" and by some young women in folk costumes who, while dancing and singing, offered them the "farmer's breakfast" made of fried bread with sugar or wine, cooked at the time, thus allowing a direct contact with cooking traditions through the five senses. The "temporary citizens" could revive some important moments of the ancient community life, such as the grape crushing by feet or the clothes washing in the public washhouse called "il Piscero" where, according to the tradition, by drinking water the "stranger" becomes castelluccese. Then, it began the village guided visit with the Mayor and BAI tutor of Castelluccio, Maria Manuela Circelli. It included a visit to the traditional mill, still operating, a symbol of the relations among food, territory, and cultural identity; a view of the landscape from the belvedere Figure 2; and a visit of the museum, opened on 3 August 2018 and focus on the "Sistema museale della Valle del Celone", as well as the Main Church and the Byzantine tower, the oldest evidence of Castelluccio Valmaggiore. After participating in a hand-made pasta workshop and listening to a poetry reading in the local dialect, the lunch began. It took place in the centre of the village, in front of the Main Church Figure 3 and it was 
a significant moment of conviviality, a time for socializing and sharing among residents and travellers, a re-enactment of ancient meals in friendship and happiness, an example of authentic relationships and genuine dishes (sausages, bean soup, "Spezzatielle", that is local lamb with chicory, eggs and pecorino cheese, and local wine).

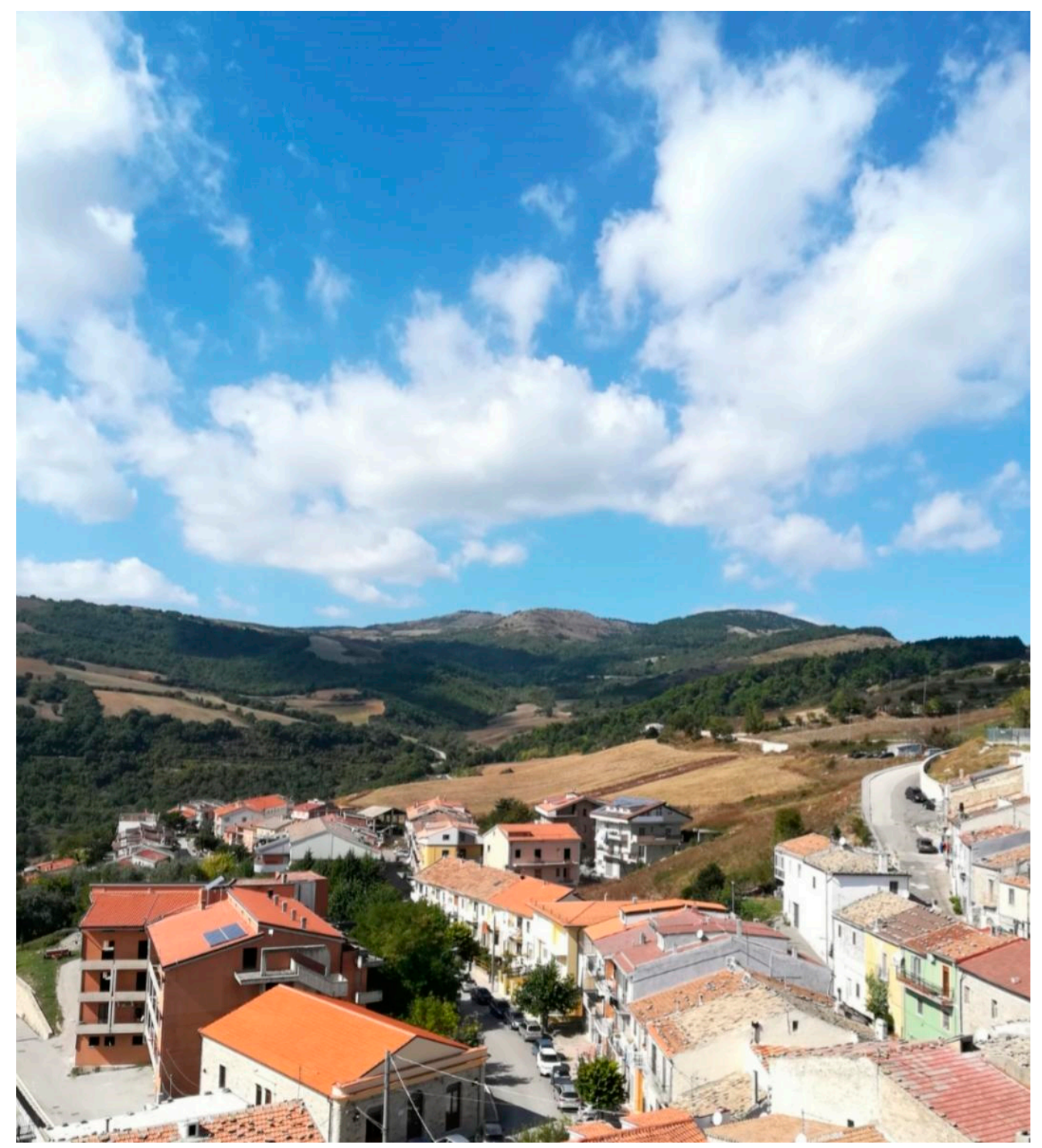

Figure 2. Castelluccio Valmaggiore: view from the belvedere (ph. F. Rinella, 30 September 2018).

The data provided by the municipal administration show that about 300 daily vouchers were sold; $80 \%$ of the event participants came from the Province of Foggia, while 20\% from the provinces of Bari and BAT.

Overall, the village of Castelluccio Valmaggiore, by actively participating in the final event of the project "Comunità del cibo buono e autentico", proved its ability to fully capture the opportunity offered by BAI, especially valuable for the inland municipalities that, due to their small size or organizational weakness, cannot aspire to become the destination of significant tourist flows, but made a strength of their "being small" (not surprisingly, Castelluccio's motto is "Parva sed apta mihi" - that is "small but suitable to me"). Unfortunately, after that event, as confirmed by the BAI tutor in a telephone interview carried out in November 2020, no new initiatives were organized, probably due to the unavailability of resources to allocate to such forms of promotion. We hope that SNAI Area Strategy could again engage the local community in a process which E. Cohen 
and S. A. Cohen define as "hot authentication" [53] (p. 1303) deeply rooted in the "daily life flow" (ibidem, p. 1300) and, therefore, focused on "flavours" and "smells", territorial basis of the identity of a "small" community, but suitable to the need and wishes of many "temporary citizens" in search of new "destinations to experience" [40].

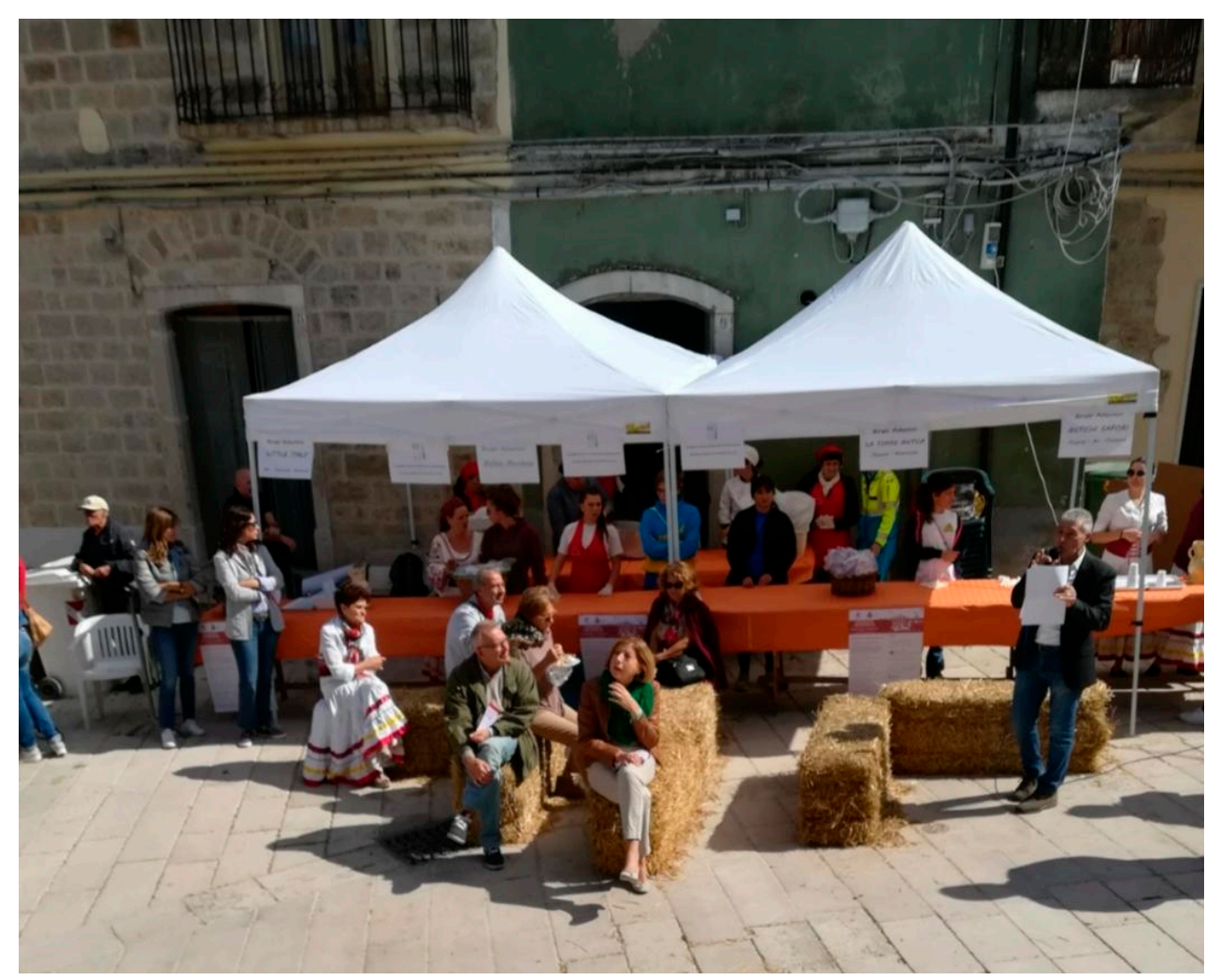

Figure 3. Castelluccio Valmaggiore: the lunch set in front of the Main Church (ph. F. Rinella, 30 September 2018).

4.2. "Alberone pare Na Zita Bianca-Vestite..." ("Alberona Looks Like a Bride all Dressed in White")

Some years ago, the ancient medieval village of Alberona, located at $732 \mathrm{~m}$ a.s.l. on the slopes of Monte Stillo, framed by a changing wood landscape, with its small community of 902 inhabitants started a series of initiatives aiming to counteract the demographic decline, thus showing a remarkable capacity of interaction with the supra-local level. In 2002, it was the first Apulian municipality to be awarded the Orange Flag by the Touring Club Italiano (TCI) [54]; further, for several years it was part of the association Borghi Autentici d'Italia (BAI) [34] and belongs now to the network I Borghi più belli d'Italia [35]. Alberona, where one of the national Unesco Club is located [55], is the main location of the Festival della Dieta Mediterranea, whose first edition dates back to 2013, and through which it has been possible to increase every year the presence of visitors, who, during three days, have the opportunity not only to participate in the wide scientific programme involving experts and scholars of great renown, but to get inside the life of the village, becoming integral part of an event for and with the community.

The latest editions were sponsored by other neighboring municipalities (who in some cases also participated), thus further consolidating the alliance and the network created among and around those small villages. In particular, the last edition, held on 27, 28 and 29 September 2019, also actively involved the municipalities of Troia and Lucera, that had the opportunity to host, each of them for one of the three days, the festival within their territories. The primary concern of the seventh edition was the agri-food identity of the territory, combining innovation and sustainability. These topics were addressed not only through meetings and debates, but also by guided tours, workshops and visits. The event was organized by four Unesco Clubs (Alberona and Lucera, in cooperation with 
Cassano delle Murge and the Vulture Unesco Club), the Rotary Club and the Lions Club of Lucera, the Inner Wheel of Cava de' Tirreni, the Federazione dei Club e dei Centri per I'Unesco Italiani (FICLU) and the partnership of the LAG Meridaunia; "the protection and promotion of the values of Mediterranean diet" explains Orfina Scrocco, President of the Alberona Unesco Club, "go through the enhancement of agri-food identities, knowledge and traditions of our territory, which, combined with technological innovation, represent a wealth to make known and to share in order to create an intercultural dialogue" [56].

The enhancement of the agri-food identity and in particular of the local food and wine culture, also include a number of events held in the months of July and August, during which several tourist facilities of the village take turns in promoting the typical dishes of the Alberona cooking (a different dish for each structure).

Further, Alberona is the location of the International Poetry Award "Borgo d'Alberona", organized since 2006 to pay a tribute and to promote the ancient poetic and literary vocation of the village, historically represented by poets as Giacomo Strizzi (1888-1961), Vincenzo D'Alterio (1940-2000), Camillo Civetta (1870-1960), and Michele Caruso (1892-1967) as well as by the "Gazzetta letteraria alberonese", published since the first decades of 1900 and currently kept in the municipal Antiquarium. Moreover, to the above prominent representatives is dedicated the "Muro della poesia" or "Muraglione dei poeti", a monument unveiled on 22 August 2010, during the awards ceremony of the fifth edition of the poetry contest. It shows the image of the four Alberona's artists, who become ambassadors of the visitors through the dialect verses of their works, engraved on the monument, narrating the home village: "Quante je bbèlle 'stu pajése méje, mbacce a 'na muntagne arrampecate! Se lu guarde da sotte e da luntane, "na mandre janche d'ajeniddhe pare" (how beautiful is my village perched on a mountain! If you look at it from below and from afar it looks like a flock of white sheep)" [57]; "Pped'a di Montahure, sop'a na ripa vèrde, Alberone pare na zita bianca-vestite" (At the foot of Montauro, on a green slope, Alberona looks like a bride all dressed in white)" [58] (Figure 4). The monument, created on the occasion of the hydrogeological restoration works of the wall below the Town Hall, shows how very practical needs can effectively combine with a highly identitarian urban regeneration, leading to new forms of enhancement and attraction.

The municipal administration was indeed commendable for their ability to intercept several forms of public financing (Province, Region, EU) to promote the upgrade of the road network, the recovery of the hydrogeological instability, the enhancement and protection of the environmental and anthropic resources. Particularly noteworthy are the works, still in progress, for the upgrade and recovery of the hydrogeological instability in the sports field area, funded by the ERDF/ESF ROP Puglia 2014-2020 (axis V, action 5.1), supplemented by the project for the extension of the existing sport facilities and the creation of a nature trail; the interventions for the restoration and upgrading of seven fountains (Fontana Muta see Figure 5, Fontanella, Pisciarelli, Fontanino di piazza Civetta, Fontana del Pozzo, Fontana di via Belvedere, Fontana del Monumento ai Caduti), that will create a walking path and cycleway within the village, also known as "town of water" or "one hundred fountains village"; lastly, the repair of the pavement of some areas of the historical centre by regional funds. Huge interventions, carried out through different financing, also concerned the road network, thanks to which it was possible to fully recover the external connection roads of the village as well as many of its internal roads, with a positive impact on the accessibility and availability of the places by whoever wishes to live in them or reach them; the works for the improvement of public lightning, thank to which it was possible not only to install LED lamps on the whole municipal territory, but also LED spotlights to enlighten the main public and cultural buildings for the benefit of residents and tourists; the installation of the required signs, previously missing, to reach, from the village, the nature trail " $U$ canale di tegghje" (channel of the baking pans. The name derives from the peculiar shape of the small falls created by water and stones) through which it is possible to reach the wood, the river and the small falls created by water and stones along its stream and that give the name to the place. Among the financing proposals submitted but still pending, the following are 
to be mentioned: (1) the project for an underground museum network, to be managed by a community cooperative composed of Alberona young people, for which an allocation of EUR 1,000,000 was applied for to the MiBACT; (2) the project for the construction of a panoramic cableway to connect the village to the top of the Monte Crocione-Pagliarone, for which an allocation of EUR 14 million has been applied for to the central Government, to be complemented by nature trails and rest areas, a bicycle parking station and the recovery of sheep tracks $[59,60]$.

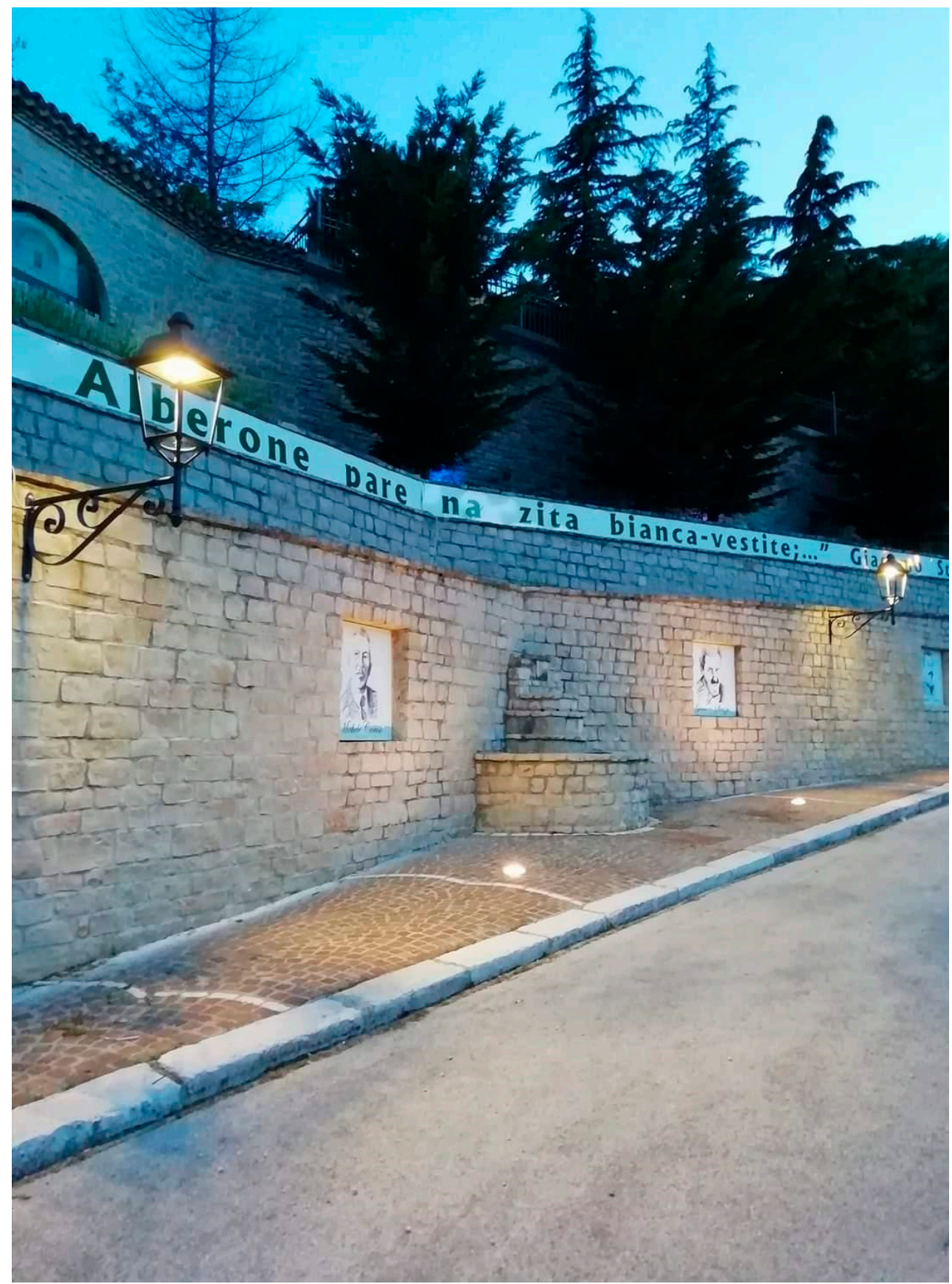

Figure 4. Alberona: the "Muro della Poesia" (photo courtesy of the Mayor of Alberona, Leonardo De Matthaeis). 


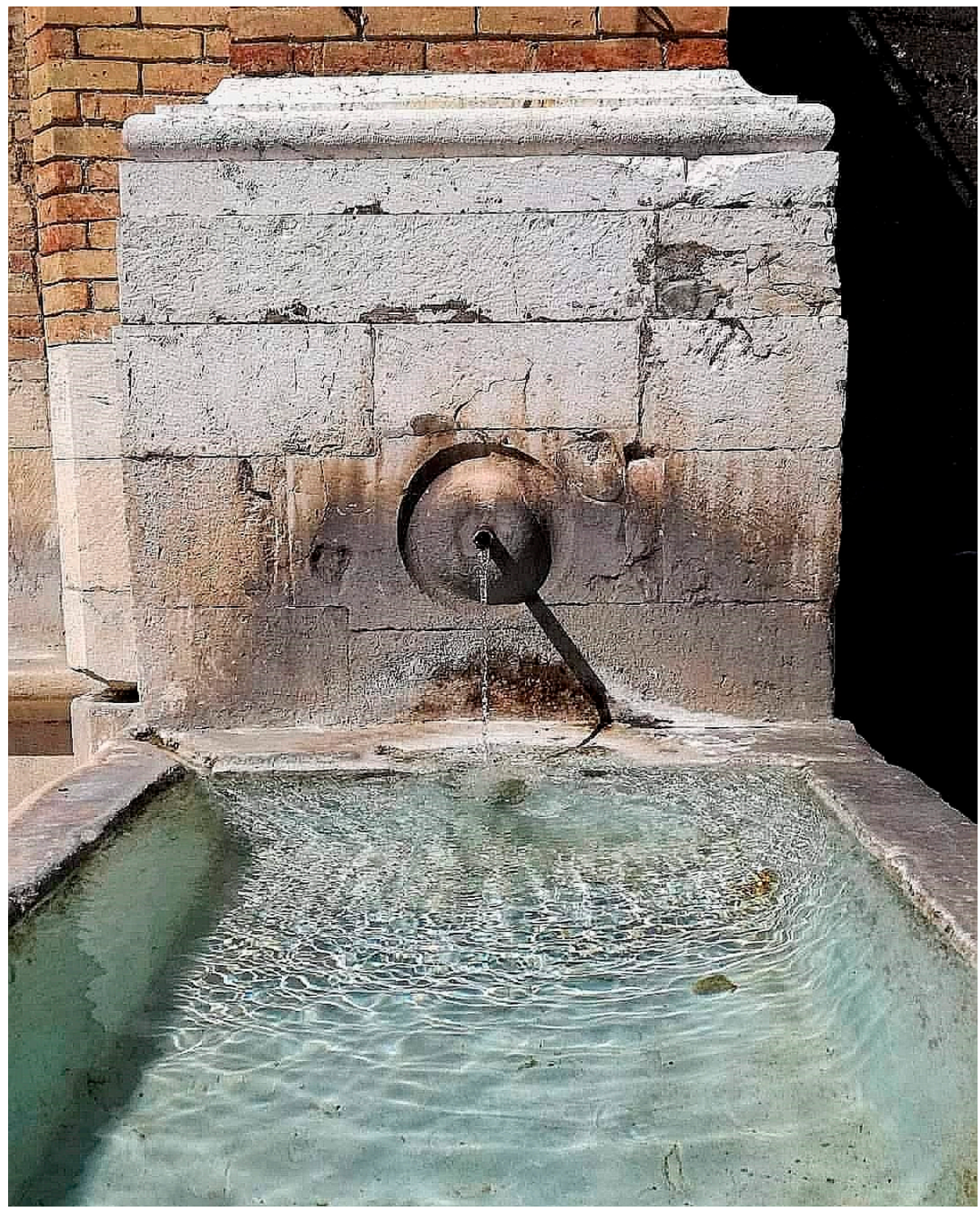

Figure 5. Alberona: detail of Fontana Muta. The name of the brick and stone monumental fountain, built in 1824 and located on the public road, comes from its original function of resting and exchange place for horses and couriers. The fountain has five spouts, two troughs, and a washtub (photo courtesy of the Mayor of Alberona, Leonardo De Matthaeis).

One last remark concerns the "virtual" promotion: indeed, even though the information on the village and its initiatives are conveyed in a detailed though fragmentary manner through several digital channels, whether institutional or not, and local on-line newspapers [54-56,59-62], actually they are not easily accessible to those who wish to investigate and explore Alberona's tangible and intangible heritage before reaching the place, with a negative impact on the potential multiplier effect of the above mentioned events. To give Alberona full imageability [63], it is necessary to grant that information high findability [44] (p. 55) through an updated website, well indexed by search engines and available in foreign languages, as being invisible on the Internet "in the Google era is like not existing at all" [ibidem] (p. 47). This gap could be filled precisely through SNAI targeted actions, in view of a self-enhancement path aimed at the systemic recovery of the Monti Dauni territorial resources and able to attract soft tourism, in search of a genuine experience, experienced according to environmental, cultural, economic, and social sustainability. 


\subsection{Biccari: When "Being a Community" Creates "Cooperation"}

The beneficial effects of a mixed top-down/bottom-up transcalar approach as the one proposed by SNAI are detected in a more immediate, evident, and effective way in the local systems used to collaborate within voluntary, supra-local networks whose objectives appear fully in line with those set out by the Area Strategy of the Monti Dauni.

This is the case of Biccari, a town with 2696 inhabitants located in the Monti Dauni Sub-Region (Table 1, Figure 1), whose Mayor, Gianfilippo Mignogna, in office since 2009 and reconfirmed in 2019 at the head of the Biccari community for the third mandate, is also Deputy Vice President of BAI, the association promoting, together with Legacoop, a national initiative aimed at experimenting the model of the "community cooperatives", one of the possible forms of civil economy enterprise based on the principle of social and environmental sustainability [64]. By stimulating the autonomy, the citizens' organizational capacity and the sense of belonging [65], the initiative, launched in the wake of similar experiences in France, United Kingdom, Germany, and Greece, strategically aims at producing "site-specific" advantages, by strengthening the territorial fabric and its capacity to influence the welfare level of the local community. Such institution, that becomes an entrepreneur to meet collective interests [66], may thus play a key role in promoting those paths defined by Magnaghi as "bottom-up globalization" [67] (p. 309), aimed at actively engaging local community members, setting the direction of shared territorial actions.

Apulia was the first Italian Region to regulate the institution of the community cooperative (Regional Law No. 23 of 20 May 2014), considering it as a preferential entity to implement active labour policies aimed at creating new jobs starting from the enhancement of the territorial tangible and intangible assets, in order to meet the requirements of the local communities and, more in general, to create social capital [68] (p. 17.870).

In November 2018, Apulia regional authorities funded the first three Apulian instances of community cooperative. Among them, the Cooperativa di Comunità di Biccari (CCB), being specifically production-oriented, qualifies as a social initiative aimed at reducing the weakness of the local system of tourist offer and to focus it on experiential tourism, based on the increasingly common desire "to see life as it is really lived even to get in with the natives" [41] (p. 592).

The CCB, set up on 7 June 2017, was designed by the Organising Committee as a real intra-generational agreement for and with Biccari young people: this is why 6 out of 7 members of the Board of Directors are citizens under 35. By entrusting the CCB free of charge a hardly or not at all used public heritage (the forestry nursery "Orto di Zolfo", mountain areas, former school building, gymnasium, etc.), into which start and manage insider and outsider services, the Municipal Administration intends to transform the "territory-heritage" in "territory-project" [69], by consolidating the capital and emotional investment of the local community in collective heritage and its appreciation. Such main mission could be complemented by the provision of social services (e.g., elderly care, leisure activities for children, etc.), as well as the management of uncultivated land and, above all, vacant/abandoned houses in the historical centre, for example by creating a community hotel [70].

The first step of the CCB was the upgrading the works of the kiosk near the lake Pescara, currently used for as tour booking and a refreshment point for tourists. Part of the Monastery of the Frati Minori di Puglia, located at $1 \mathrm{~km}$ from the town, was turned into a hostel and entrusted to the management of the CCB, within the AIG (Associazione Italiana Alberghi per la Gioventù) network; during summer 2017 when the facility hosted 200 guests. During the BAI National Festival held in Biccari on 15-17 June of the same year, about 10,000 visitors were estimated, with 70 overnight stays in the municipal territory, as well as the engagement of 20 resident members in the activities related to the event organization. Furthermore, thanks to a municipal finance facility of EUR 13,000, the InfoPoint of Piazza Municipio was opened, where five resident members work.

An aspect particularly significant in geographical terms is the increase of the rate of proactivity of local players, to which the enhancement of the links of cooperation surely 
contributes. This is firstly evidenced by the remarkable planning: during 2017 the CCB was awarded financing facilities relating to three regional calls for the organization of attraction events, such as cycling tours, trekking, activities, and visits concerning local products, with significant positive effects on economy and employment also for the neighbouring towns. Added to this is the strong inclination to widen the collaborative networks: we refer to the mapping of uncultivated land, carried out with ARIF (Agenzia Regionale attività Irrigue e Forestali) and which lead to a memorandum of understanding between the ARIF and the Municipality of Biccari concerning the return to the latter of about 2 ha of the forestry nursery entrusted to the CCB and now dedicated to the production of wild berries, or the participation of Biccari in the IT.A.Cà national network, by hosting the first edition of the Festival del turismo responsabile dei Monti Dauni.

The pilot activities, experimented through the funded projects, featuring a "virtual" image since inception thanks to the official website [71] and to the app "WhatsCoop", which allows to receive free updates on initiatives, events and meetings, have now transformed into a permanent offer of comprehensive and diversified packages. The proposals include trekking and cycling tours, weekends, truffle hunting, archery, triathlon, laser tag, and paintball. Further, picnic baskets containing certified local products, such as truffle cream and the "pizza a forno aperto"; or the "Bubble Room", a mini pop-up house with clear walls and ceiling to sleep under the stars, fully immersed in the wood magic near the lake Pescara. Presently, the offer is focused on food and wine and the nature attractions of the area of the Monte Cornacchia and the lake Pescara, but the activities also concern the historic centre. From September 2019 a tourist portal is on-line [72], whose contents are now also available in English. For its implementation all the stakeholder (shops, B\&B, restaurants, associations, etc.) were invited to send photos, videos, texts, and useful information on their business that were published for free.

However, the role played by the CCB in strengthening the autopoietic characteristics of the Biccari territorial system does not appear only in its contribution to the metabolizing processes of positive incentives (in the specific case, the capacity to find financing facilities through the enhancement of a shared planning): indeed, after the Covid-19 onset, it strongly aroused the pivotal function of the CCB in orienting "resistant" actions, with incremental effects on overall resilience levels of the system. In particular, "Artisti Riuniti" was the first initiative of the CCB, held on-line right during the Italian lockdown (9 March-18 May 2020): it was a real charity auction to support the Policlinico Ospedale Riuniti of Foggia, main health facility of the area, severely tested by the health emergency. The initiative was also made possible thanks to some local artists who donated their works to sell. The proceeds were delivered in August 2020 during an exhibition of the auctioned works of art.

The BICs (Buoni Incentivo Comunitario) are discount vouchers issued by the Municipality. Launched in June 2020 and expiring in May 2021, they are applied for by tourists/visitors and used at shops and accommodating facilities participating in the initiative. The businesses cashing the vouchers, in turn, may reuse them at other businesses of the town. There is a dual purpose: from one side, relaunching tourism in a period of deep crisis and, in general, increasing the number of customers of local players; on the other side, also through the BICs reuse, retain in Biccari those financial resources, thus supporting the local economy by preferring internal consumption, thus enhancing the community cohesion.

"PerDopo" is a coupon for a postponed drink or meal, conceived on the basis of similar experiences at the national level and replicated by the Biccari community. Through the on-line payment it was possible, during the lock-down as well as in the following restriction period starting from November 2020 and still in progress in Italy, to purchase drinks or meals at bars, restaurants, and pizzerias of the town, thus supporting one of the economic sectors more affected by the measures preventing the spread of the Covid-19 contagion.

Finally, the traditional Christmas market that in previous years, during the November and December weekends, attracted a large number of visitors in the small Daunian town, in 2020 a new system has been proposed. In order to support craftsmen and small local 
producers, to whom the market was an important opportunity for visibility and profit, the official website of the cooperative [72] provides a real on-line showcase, allowing producers to offer their products and making them available for on-line purchase. Apart from the specific needs related to the Covid-19 emergency, which lead to adopting this new business channel, the above experience may of course represent a test for small producers and local craftsmen who are interested in making their products known to a wider public; in this case, it is particularly clear the driver role played by the CCB that, besides making concretely possible an experience otherwise unsustainable by single producers, proposing itself as "territorial aggregator" enhances the placeness of the products offered, which therefore acquire an added value clearly perceived by potential purchaser.

Thus, the initiatives launched to tackle the health emergency also highlight the CCB attitude to act according to a "variable range" mode. All the initiatives are first of all conceived to meet the requirements of diversified targets: the community in the first place (the hospital, as an essential reference service; local businesses and producers, as active and central members of the system), but the experiential tourist as well, through the invitation to support the territory, widening its status of temporary citizen beyond the contingent experience and increasing the engagement level. The initiatives also achieve different goals, ranging from the economic support to the launch of active citizenship practices; likewise, the effects range from short- to long-term. This shows, on one side, the complex analysis of effects and players and, on the other side, an approach to an emergency whereby actions are designed to tackle effectively both the extraordinary conditions and the structural effects; the latter aspect provides a planning action to prevent the spreading of the social and economic effects of the pandemic on a clearly programming and not only contingent level.

\section{Conclusions}

An economy depending on an unprofitable or declining agriculture, trade and services contraction, sharp depopulation and population ageing, poor enhancement of existing resources and/or potentials, social and economic stasis, and conservative and traditional forms of territorial organization and ways of life: these are the features common to most of the settlement network of Italian inner areas, rich in small towns, the so-called "borghi", away from tourist circuits featuring "imageability" [63]. Despite such marginal conditions, in recent years some of them showed the intentions to become sustainable and responsible communities, able to open themselves, to include and to look with hope beyond the decline, changing their route, instead of closing in on themselves. They are local systems with the precise goal to create new development prospects based on the enhancement of their own "raw materials", represented not only by environmental and cultural heritage, but by a set of intangible assets (quality of life, social cohesion, human capital, and flavors and knowledge of the territory) considered as concrete opportunities of rebirth. Thus, the communities can become key players of a real "hot authentication" path according to the definition given by E. Cohen and S. A. Cohen [53] of their milieu, initiating a "recreational re-ruralisation" [73] (p. 206) that catches the interest of travellers in search "a break to replenish energies and regenerate" [33] (p. 20), creating "unprecedented forms of economy and socialization and building new-ancient meeting places" (Ibidem).

If today, in the settlement network of Italian inner small towns, not lacking in discontinuities and patches, a resistant "common thread" is noticeable, which allows to overcome optimistically several weaknesses, this is due not only to the firm "restance" [74,75] of the many individual or collective "custodian of the territory" present, but also to the new way of thinking and implementing the social and spatial justice [76] initiated by the SNAI, with a mixed top-down/bottom-up approach, who acts as an institutional framework for the placed-based processes of local development. Likewise at a national level, voluntary networks as "Borghi Autentici d'Italia" [34,48] and "Borghi più belli d'Italia" [35] represented, and still do, an empowering environment for small-sized local systems with poor planning capacities, due to a marked political and institutional, as well as geographical, peripheral condition. Among the administrative regions, the far-sightedness of Apulia in putting in 
place a regulatory instrument as the Regional Law No. 23 of 20 May 2014 (see $\S 4.3$ ) not only represents a general sensitivity of institutions, but also a strong intervention capacity, due to a deep knowledge of territorial weaknesses and potentials.

In December 2020, the SNAI testing phase will end, with the obligation of terminating all the Framework Programme Agreements (FPA) stipulated by the 72 "project areas" in order to proceed to the next structural phase of full implementation of the planned interventions. Notwithstanding the bureaucratic issues due to the difficulty of quickly coordinate a large number of entities-central ministry administrations, Regions and Municipalities [77] - multiple positive and innovative elements of this testing lead the European Parliament, in April 2019, to include the "SNAI model" positive features in the ERDF 2021-2027 planning [78] (p. 9).

The Monti Dauni pilot area does not lack in tourist enhancement initiatives to target. Sometimes they are incidental, as in the case of Castelluccio Valmaggiore ( $\$ 4.1)$, sometimes they are systemic but still lacking "imageability" [63], as in the Alberona community (§4.2), up to mature capitalization forms as in the case of Biccari (§ 4.3): in particular, this latter local system seems able of metabolizing all the external incentives, both positive (regional, national, and EU financing facilities) and negatives (Covid-19 pandemic), operationally conveying them into what Raffestin [79] calls the "actor's programme", that is a real territorial project which appears to be endogenous and self-centred, constantly self-perpetuating. The main development driver of the network appears to be the "innovating" administrator (with similar characteristics to the entrepreneur described by Schumpeter) [80], in the person of the Mayor Gianfilippo Mignogna, also Vice President of BAI, able to continuously promote the interaction between Biccari's small community and the supra-local contexts.

In the light of the above, it seems clear that the present and future task of inner areas governance in Italy shall be the strengthening of two key skills: "creating the local society" [58] (p. 80) and "nurturing the amor loci" [81], essential elements to promote a "bottom-up globalization" to which every local player has to participate "to make a direct contribution to the production, care and reproduction of its own life and relationship environment, creating new interconnections among individual activities and social purposes of production and consumption, widening the values of use, the non-negotiable shared assets, the off-the-market activities able to initiate multiple forms of mutually supportive exchange" [67] (p. 309). At the same time, the qualities seen by Caravaggi and Imbroglini [82] as peculiar to "resilient" local systems shall be strengthened: flexibility, inclusiveness, integration and, above all, resourcefulness, which is "the ability to achieve economic viability goals and development prospects through new creative and innovative avenues" [Ibidem] (p. 148).

Author Contributions: For research articles with several authors, a short paragraph specifying their individual contributions must be provided. The following statements should be used "Conceptualization, A.I., A.R.; methodology, A.I., A.R., F.R., F.E., S.N.; investigation, A.I., A.R., F.R., F.E., S.N.; writing—original draft preparation, A.I., A.R., F.R., F.E., S.N.; writing—review and editing, A.I., A.R., F.E.; visualization, S.N.; supervision, A.I., A.R." Please turn to the CRediT taxonomy for the term explanation. Authorship must be limited to those who have contributed substantially to the work reported. Although both theoretical framework and Conclusions are shared by the Authors, Sections 1 and 2 are to be attributed to A.I., Section 3 to A.R., Sections 4 and 4.1 to F.R., Section 4.2 to S.N., Section 4.3 to F.E. All authors have read and agreed to the published version of the manuscript.

Funding: This research received no external funding.

Conflicts of Interest: The authors declare no conflict of interest.

\section{References}

1. Pezzi, M.G.; Urso, G. Peripheral areas: Conceptualizations and policies. Introduction and editorial note. Ital. J. Plan. Pract. 2016, 6,1-19.

2. Agenzia per la Coesione Territoriale. Strategia Nazionale per le Aree Interne: Definizione, Obiettivi, Strumenti e Governance. 2013. Available online: https:/ / www.programazioneeconomica.gov.it (accessed on 3 February 2021). 
3. Ugolini, G.M. Il rilancio delle aree rurali marginali: Anche una questione di progetto culturale. In Risorse Culturali e Sviluppo Locale; Madau, C., Ed.; Società Geografica Italiana: Rome, Italy, 2004; pp. 47-62.

4. Ciaschi, A.; De Iulio, R. Aree Marginali e Modelli Geografici di Sviluppo. Teorie e Esperienze a Confronto; Editore Sette Città: Viterbo, Italy, 2014.

5. Sommella, R. Un gruppo di lavoro sulle vie interne allo sviluppo del Mezzogiorno. Geotema 1998, 10, 7-8.

6. Cencini, C.; Dematteis, G.; Menegatti, B. L'Italia Emergente. Indagine Geo-Demografica sullo Sviluppo Periferico; Franco Angeli: Milan, Italy, 1983.

7. Coppola, P. L'osso e i suoi quesiti. Geotema 1998, 10, 3-6.

8. Società Geografica Italiana. Politiche per il Territorio (Guardando all'Europa). Rapporto Annuale 2013; Società Geografica Italiana: Rome, Italy, 2013.

9. Celant, A. (Ed.) Ecosostenibilità e Risorse Competitive. Le Compatibilità Ambientali nei Processi Produttivi; Società Geografica Italiana: Rome, Italy, 2000.

10. Manzi, E. Centri minori tra geografia, urbanistica, beni culturali e ambiente. Spunti per una ricerca e un dibattito. Rivista Geografica Italiana 2000, 2, 255-272.

11. Antolini, F.; Billi, A. Politiche di Sviluppo nelle Aree Urbane; UTET: Turin, Italy, 2007.

12. Dipartimento Politiche Europee-Presidenza del Consiglio. Documento di Economia e Finanza. 2006. Available online: https:/ /rgs.mef.gov.it (accessed on 2 December 2020).

13. Legge no. 147/2013, G.U. 27/12/2013. Available online: https://www.gazzettaufficiale.it/eli/id/2013/12/27/13G00191/sg (accessed on 8 March 2021).

14. Legge no. 158/2017, G.U. 02/11/2017. Available online: https://www.bosettiegatti.eu/info/norme/statali/2017_0158_piccoli_ comuni.htm (accessed on 8 March 2021).

15. Turco, A. Configurazioni della Territorialità; Franco Angeli: Milano, Italy, 2010.

16. Harvey, D. Space as Keyword. In David Harvey. A Critical Reader; Castree, N., Gregory, D., Eds.; Blackwell: Malden, UK, 2006; pp. 270-293.

17. Dematteis, G. Regioni geografiche, articolazione territoriale degli interessi e regioni istituzionali. Stato Mercato 1989, $27,445-467$.

18. Mannella, S. L'ambiente e l'agricoltura. In Scritti geografici sul Subappennino Dauno; Mannella, S., Fiori, M., Carparelli, S., Mininno, A., Varraso, I., Eds.; Pubblicazioni del Dipartimento di Scienze Geografiche e Merceologiche, Università degli Studi di Bari; Adriatica Editrice: Bari, Italy, 1990; pp. 9-36.

19. Mannella, S.; Fiori, M.; Carparelli, S.; Mininno, A.; Varraso, I. Scritti geografici sul Subappennino Dauno; Pubblicazioni del Dipartimento di Scienze Geografiche e Merceologiche, Università degli Studi di Bari; Adriatica Editrice: Bari, Italy, 1990.

20. Bissanti, A.A. La Dimora Rurale nel Tavoliere e nel Subappennino Dauno; Memorie Istituto di Geografia, Facoltà di Economia e Commercio, Università degli Studi di Bari, NS 3; Tipo Sud: Bari, Italy, 1968.

21. Bissanti, A.A. La Puglia. In I Paesaggi Umani; Touring Club Italiano (TCI): Milan, Italy, 1977; pp. 166-179.

22. Bissanti, A.A. Puglia. Geografia Attiva; Adda: Bari, Italy, 1991.

23. Rinella, A. Ripensare la realtà di un'area depressa: Il caso del Subappennino Dauno. Economia e Commercio 1990, 3, 3-18.

24. Novembre, D. Puglia. Popolazione e Territorio; Milella: Lecce, Italy, 1979.

25. Amoruso, O. Progresso e regresso demografico nei comuni pugliesi: Una prima individuazione di ambiti spaziali. In $L^{\prime}$ Italia Emergente. Indagine Geo-Demografica sullo Sviluppo Periferico; Cencini, C., Dematteis, G., Menegatti, B., Eds.; Angeli: Milan, Italy, 1983; pp. 499-517.

26. Varraso, I. L'esile copertura antropica della "montagna" pugliese. In Scritti Geografici sul Subappennino Dauno; Mannella, S., Fiori, M., Carparelli, S., Mininno, A., Varraso, I., Eds.; Pubblicazioni del Dipartimento di Scienze Geografiche e Merceologiche, Università degli Studi di Bari; Adriatica Editrice: Bari, Italy, 1990; pp. 103-126.

27. Emanuel, C. Patrimoni paesistici, riforme amministrative e governo del territorio: Svolte e percorsi dissolutivi di rapporti problematici. Boll. Soc. Geogr. Ital. 1999, 4, 295-318.

28. Banfield, E.C. Le Basi Morali di una Società Arretrata; Il Mulino: Bologna, Italy, 1976.

29. GAL Meridaunia. Strategie di Sviluppo Locale "Monti Dauni". Programmazione 2014-2020. 2014, p. 76. Available online: http:/ / www.meridaunia.it/upload/PAL_GAL_MERIDAUNIA\%202014-2020.pdf (accessed on 8 March 2021).

30. GAL Meridaunia. Monti Dauni. La Puglia da Scoprire. 2015, p. 180. Available online: http://www.meridaunia.it/upload/upl1 /Guida\%20GAL\%20Meridaunia\%20-\%20WEB.pdf (accessed on 8 March 2021).

31. Regione Puglia. Piano Paesaggistico Territoriale Regionale; (Scientific Director: A. Magnaghi), Document no.5 Ambito 2/Monti Dauni, February 2015. Available online: http:/ / www.paesaggiopuglia.it (accessed on 2 December 2020).

32. Legge no. 64/1986, G.U. 14/03/1986. Available online: https://www.normattiva.it/uri-res/N2Ls?urn:nir:stato:legge:1986-03-01 ;64 (accessed on 8 March 2021).

33. Decandia, L. Ripensare la "società dell'azione", e ricominciare a "guardare il cielo": La montagna come "controambiente" del sublime in una inedita partitura urbana. Scienze del Territorio 2016, 4, 18-24.

34. Associazione Borghi Autentici d'Italia. Available online: www.borghiautenticiditalia.it (accessed on 2 December 2020).

35. Associazione I Borghi Più Belli d'Italia. Available online: www.borghipiubelliditalia.it (accessed on 2 December 2020).

36. Decision n. 870 of April 2015. Available online: http://burp.regione.puglia.it/en/bollettino-ufficiale?p_p_id=burpsearch_ WAR_GestioneBurpportlet\&p_p_lifecycle=0\&p_p_state=normal\&p_p_mode=view\&p_p_col_id=column-1\&p_p_col_count= 
1\&_burpsearch_WAR_GestioneBurpportlet_jspPage=\%2Fhtml\%2Fburpsearch\%2Fview.jsp \textampersand_burpsearch_ WAR_GestioneBurpportlet_opz=dettagliosezione\&_burpsearch_WAR_GestioneBurpportlet_anno=2015\&_burpsearch_WAR_ GestioneBurpportlet_burpId=15781\&_burpsearch_WAR_GestioneBurpportlet_sezioneId=4574633\&_burpsearch_WAR_ GestioneBurpportlet_delta=75\&_burpsearch_WAR_GestioneBurpportlet_keywords=\&_burpsearch_WAR_GestioneBurpportlet_ advancedSearch=false\&_burpsearch_WAR_GestioneBurpportlet_andOperator=true\&_burpsearch_WAR_GestioneBurpportlet_ resetCur=false\&_burpsearch_WAR_GestioneBurpportlet_cur= (accessed on 8 March 2021).

37. Regione Puglia. Deliberazione della Giunta Regionale n. 951 5/6/2018. Available online: https:/ /www.burp.regione.puglia.it (accessed on 2 December 2020).

38. Woodward, K.; Jones, J.P., III; Marston, S.A. Of eagles and flies: Orientations toward the site. Area 2010, 42, 271-280. [CrossRef]

39. Massey, D. For Space; Sage: London, UK, 2005.

40. MiBACT (Ministero per i Beni e le Attività Culturali e per il Turismo). Piano Strategico di Sviluppo del Turismo 2017-2022. 2016, p. 112. Available online: http:/ / www.turismo.beniculturali.it (accessed on 2 December 2020).

41. MacCannell, D. Staged Authenticity: Arrangements of Social Space in Tourist Setting. Am. J. Soc. 1973, 79, 589-603.

42. MacCannell, D. The Tourist: A Theory of the Leisure Class; Schocken: New York, NY, USA, 1976.

43. Martinego, M.C.; Giaccaria, P. Autenticità e radicamento nel turismo esperienziale. Introduzione. In (S)radicamenti; Dansero, E., Lucia, M.G., Rossi, U., Toldo, A., Eds.; Società di Studi Geografici, Memorie Geografiche: Firenze, Italy, 2017 ; pp. 513-514.

44. Ferrari, S. Modelli Gestionali per il Turismo come Esperienza. Emozioni e Polisensorialità nel Marketing delle Imprese Turistiche; Cedam: Padua, Italy, 2006.

45. Rossi, A.; Goetz, M. Creare Offerte Turistiche Vincenti con Tourist Experience Design; Hoepli: Milan, Italy, 2011.

46. Mariotti, A. Beni comuni, patrimonio culturale e turismo. Introduzione. In Commons/Comusne; Società di Studi Geografici, Memorie Geografiche: Firenze, Italy, 2016; pp. 437-438.

47. Rabbiosi, C. Turismo esperienziale e narrazione selettiva dei luoghi: Il ruolo delle comunità residenti. In (S)radicamenti; Dansero, E., Lucia, M.G., Rossi, U., Toldo, A., Eds.; Società di Studi Geografici, Memorie Geografiche: Firenze, Italy, 2017 ; pp. 521-527.

48. Rinella, A.; Rinella, F. Dalle tessere marginali al mosaico progettuale in rete: Le proposte di sviluppo locale dell'associazione 'Borghi Autentici d'Italia'. In Ripartire dal Territorio. I Limiti e le Potenzialità di una Pianificazione dal Dasso, Atti del X Incontro ItaloFrancese di Geografia Sociale (Lecce, 30-31 March 2017); Pollice, F., Urso, G., Epifani, F., Eds.; Placetelling ${ }^{\circledR}$ Collana di Studi Geografici sui Luoghi e sulle Loro Rappresentazioni, Università del Salento: Lecce, Italy, 2019; pp. 211-223. ISBN 978-88-8305-145-6.

49. Rinella, A.; Rinella, F. Verso una narrazione creativa e originale della montagna: Il Sistema delle Comunità Ospitali dei Monti Dauni. Boll. Soc. Geogr. 2018, 14, 69-78.

50. Garibaldi, R. Viaggio per cibo e Vino. Esperienze Creative a Confronto; Aracne: Rome, Italy, 2017; Volume II.

51. Finocchi, F. Geografie del Gusto; Aracne: Rome, Italy, 2010.

52. Rinella, F. Processi di autenticazione e turismo dei "sapori" e dei "profumi": Il progetto "Comunità del cibo buono e autentico. In Mosaico/Mosaic; Cerutti, S., Tadini, M., Eds.; Giornata di studio della Società di Studi Geografici: Novara, Italy, 2019 ; pp. 749-758.

53. Cohen, E.; Cohen, S.A. Authentication: Hot and Cool. Ann. Tour. Res. 2012, 3, 1295-1314. [CrossRef]

54. Bandiera Arancione. Available online: https://www.bandierearancioni.it (accessed on 2 December 2020).

55. Club per l'UNESCO di Alberona. Available online: https:/ / alberonaclubunesco.it (accessed on 2 December 2020).

56. Available online: https://amp.foggiatoday.it/eventi/festival-dieta-mediterranea-troia-lucera-alberona.html (accessed on 23 November 2020).

57. Verses by M. Caruso in the Original Project of the "Muro della Poesia". Available online: https://lucerabynigh.it/18201-Alberonae-il-muraglione-dei-poeti (accessed on 2 December 2020).

58. Verses by G. Strizzi on the "Muro della Poesia". Available online: http://alberona.blogspot.com/2010/09/alberona-una-sposadi-bianco-vestita.html (accessed on 8 March 2021).

59. Comune di Alberona. Available online: https:/ /www.comune.alberona.fg.it (accessed on 2 December 2020).

60. Alberona a 5 Stelle. Available online: https://www.facebook.com/alberona-a-5-stelle-226034901094416 (accessed on 2 December 2020).

61. Mayor of Alberona's Facebook Profile. Available online: https://www.facebook.com/de.m.leonardo (accessed on 2 December 2020).

62. AlberonaComunica. Available online: https://www.alberonacomunica.wordpress.com (accessed on 2 December 2020).

63. Lynch, K. The Image of the City; MIT Press: Boston, MA, USA, 1960.

64. Mori, P.A.; Sforzi, J. (Eds.) Imprese di Comunità. Innovazione Istituzionale, Partecipazione e Sviluppo Locale; Il Mulino: Bologna, Italy, 2019.

65. Legacoop. Cooperative di Comunità. Opportunità di Sviluppo e Lavoro per il Bene Comune. 2011. Available online: www. legacoop.coop/cooperativa-di-comunità(accessed on 20 November 2020).

66. Bandini, F.; Medei, R.; Travaglini, C. Territorio e persone come risorse: Le cooperative di comunità. Impresa Soc. 2015, 5, 19-35.

67. Magnaghi, A. Il Progetto Locale. Verso la Coscienza di Luogo; Bollati Boringhieri: Milan, Italy, 2013.

68. Regione Puglia. Disciplina delle cooperative di comunità (L.R. n. 23 del 20.5.2014). Bollettino Ufficiale della Regione Puglia 2014, 66, 17.869-17.870. Available online: www.regionepuglia.it/bollettino-ufficiale (accessed on 20 November 2020).

69. Governa, F. Il Milieu Urbano. L'Identità Territoriale nei Processi di Sviluppo; Franco Angeli: Milan, Italy, 1997.

70. Pollice, F. Alberghi di comunità: Un modello di empowerment territoriale. Territ. Cult. 2016, 25, 82-95. 
71. Cooperativa di Comunità di Biccari. Available online: https:/ / www.coopbiccari.it (accessed on 20 November 2020).

72. Visit Biccari. Available online: htpps://www.visitbiccari.com (accessed on 20 November 2020).

73. Claval, P. Introduzione alla Geografia Regionale; Zanichelli: Milan, Italy, 1996.

74. Teti, V. Pietre di Pane. Un'Antologia del Restare; Quodlibet Studio: Macerata, Italy, 2014.

75. Teti, V. Quel Che Resta. L'Italia dei Paesi, Tra Abbandoni e Ritorni; Donzelli editore: Rome, Italy, 2017.

76. Reynaud, A. Disuguaglianze Regionali e Giustizia Socio-Spaziale; Unicopli: Milan, Italy, 1984.

77. Amadore, N. Strategia Nazionale Aree Interne, il Governo Spinge per Accelerare. Available online: https://www.ilsole24ore.com (accessed on 2 December 2020).

78. Martinelli, L. L'Italia è bella Dentro. Storie di Resilienza, Innovazione e Ritorno nelle Aree Interne; Altreconomia: Milan, Italy, 2020.

79. Raffestin, C. Territorialità, territorio, paesaggio. In Territorialità: Concetti, Narrazioni, Pratiche. Saggi per Angelo Turco; Arbore, C., Maggioli, M., Eds.; Franco Angeli: Milan, Italy, 2015; pp. 31-39.

80. Schumpeter, J. La Teoria Dello Sviluppo Economico; UTET: Turin, Italy, 1932.

81. Pileri, P.; Granata, E. Amor loci. In Suolo, Ambiente, Cultura Civile; Libreria Cortina: Milan, Italy, 2012.

82. Caravaggi, L.; Imbroglini, C. La Montagna Resiliente. Sci. Territ. 2016, 4, 145-152. 